\title{
Cloning of cDNA for DARPP-32, A Dopamine- and Cyclic AMP- Regulated Neuronal Phosphoprotein
}

\author{
Tatsuya Kurihara, Robert M. Lewis, Jesse Eisler, and Paul Greengard \\ Laboratory of Molecular and Cellular Neuroscience, The Rockefeller University, New York, New York 10021
}

\begin{abstract}
A cDNA clone for the mRNA of bovine DARPP-32 (dopamineand adenosine $3^{\prime}, 5^{\prime}$-monophosphate-regulated phosphoprotein, $M_{r}=32,000$ ) was isolated from a modified OkayamaBerg plasmid library. Transformed Escherichia coli colonies were screened by in situ colony hybridization with 2 different oligonucleotide probes corresponding to a region unusually rich in glutamate within the protein. Three positive clones were isolated and shown to encode DARPP-32 by an in situ immunoblot assay of their fusion protein products with $\beta$-galactosidase. The results of the sequence analysis of the longest CDNA clone, pTKD7 (1771 nucleotides), revealed a 606-nucleotide-long coding region, in exact agreement with the bovine DARPP-32 amino acid sequence (Williams et al., 1986). Southern blot analysis of total bovine genomic DNA showed that there is a single gene coding for DARPP-32. Northern blot analysis of caudate nucleus RNA using antisense RNA derived from the clone PTKD7 demonstrated the existence of 2 abundant mRNA species, corresponding to 1.8 and 1.65 kilobase in length. The high concentration of DARPP-32 mRNAs in the caudate nucleus is in agreement with the known distribution of this protein.
\end{abstract}

DARPP-32 is a neuron-specific phosphoprotein with an apparent $M_{\mathrm{r}}$ of 32,000. In rat brain, the phosphorylation of DARPP32 appears to be regulated by dopamine and cAMP (Walaas et al., 1983; Walaas and Greengard, 1984), and the phosphorylated form of the protein is a potent and specific inhihitor of protein phosphatase-1 (Hemmings et al., 1984a, c, d; Williams et al., 1986). In mammalian brain, a variety of biochemical and immunological studies have demonstrated that DARPP- 32 is highly enriched in the basal ganglia and may be restricted to the $D_{1}$ subclass of dopaminoceptive neurons (Ouimet et al., 1984; Walaas and Greengard, 1984; Hemmings and Greengard, 1986). DARPP-32-like proteins are also present in dopaminoceptive regions of bird and reptile brains but cannot be detected in bony fishes or amphibians (Hemmings and Greengard, 1986). The protein has been purified to homogeneity from bovine caudate nucleus and biochemically characterized (Hemmings et al.,

\footnotetext{
Received Jan. 29, 1987; revised July 16, 1987; accepted July 29, 1987.

This work was supported by USPHS Grants MH40899 and NS 22789. We wish to thank Dr. Jean-Antoine Girault (The Rockefeller University) for carrying out the bovine brain microdissection and stimulating discussion, Dr. Hugh C. Hemmings, Jr. (The Rockefeller University) for gifts of anti-DARPP-32 monoclonal antibodies, Drs. Shigeru Sassa, Michelle Ehrlich, Hiroyoshi Fujita, and Michael Wagner (The Rockefeller University) for their helpful comments and suggestions on this manuscript. We also wish to thank Dr. Teruhisa Noguchi (Suntory Institute for Biomedical Research) for his great interest in and support of this study.

Correspondence should be addressed to Paul Greengard, Box 296, The Rockefeller University, 1230 York Avenue, New York, NY 10021.

Copyright (C) 1988 Society for Neuroscience $0270-6474 / 88 / 020508-10 \$ 02.00 / 0$
}

1984b). The complete amino acid sequence has also been determined (Williams et al., 1986). Knowledge of the structure and organization of the DARPP-32 gene may allow us to elucidate the mechanisms of its neuron-specific expression. In this paper, we describe the isolation and characterization of a cDNA clone for bovine DARPP-32 by use of an in situ colony hybridization method with oligonucleotide probes and an in situ immunoassay. We have used this clone to study the regional distribution of DARPP-32 mRNA in bovine brain and to carry out a genomic analysis of this protein.

\section{Materials and Methods}

Bacterial strains and plasmids. Escherichia coli $\mathrm{K}-12$ strains used were WA802 [metB1, lacy or lac3, galK2, galT22, $\lambda, \operatorname{supE44,~endA,~sbcB,~}$ hsd3] (Wood, 1966; Nelson et al., 1981), JM103 [ $\Delta$ (lac-pro), thi, strA, supE, end $A, s b c B, h s d R^{-}, F^{-}$traD36, proAB, laci ${ }^{Q}, z \Delta M 15$ ] (Messing et al., 1981), and JM83 [ara, $\Delta l a c^{-}$, pro, strA, thi, $\phi 80 d$, lacz $\left.\Delta M 15\right]$ (Vieira and Messing, 1982). Plasmids included pSV7186 (Pharmacia), pUC18 (Pharmacia), pGEM3 (Promega Biotec), and the newly constructed pTK501 and pTKD7G3. E. coli strains harboring these plasmids were grown in LB medium containing $50 \mu \mathrm{g} / \mathrm{ml}$ ampicillin.

Preparation of bovine brain RNA. For preparation of RNA, caudate nuclei were dissected on ice from fresh calf brains, rapidly frozen in liquid nitrogen and stored in it until use. Total RNA $(2.8 \mathrm{mg})$ was isolated from calf caudate nuclei $(6 \mathrm{gm})$ by extraction with guanidine isothiocyanate followed by sedimentation through cesium chloride (Chirgwin et al., 1979). Poly(A) ${ }^{+}$RNA $(200 \mu \mathrm{g})$ was enriched by a cycle of oligo(dT)-cellulose Type 3 (Collaborative Research) chromatography (Aviv and Leder, 1972; Zelenka and Piatigorsky, 1974).

Construction of a novel linker plasmid for the Okayama-Berg expression system. In place of the original Okayama-Berg oligo(dG)-tailed linker DNA fragments derived from SV40 DNA (map units $0.71-0.86$ ), $E$. coli lacz containing oligo(dG)-tailed linker DNA (Pharmacia) fragments were used for cyclization of cDNA plasmids (Fig. 1). The new linker fragments were generated from pTK501 constructed from pUC18. Briefly, pUC18 plasmids were digested partially wtih $P v u I I$, which potentially cuts the middle of either laci or lacz gene. HindIII linkers (Pharmacia) were ligated onto the blunt-ended DNAs, and the ends were religated with T4 DNA ligase. Following complete digestion with $P v u \mathrm{II}$, the DNA mixture was diluted 75 -fold and self-ligated, a procedure designed to reduce the population of original pUC18 plasmid molecules. $E$. coli JM83 competent cells were transformed with the ligation mixture and plated in the presence of $0.03 \% 5$-bromo-4-chloro3 -indolyl $\beta$-D-galactopyranoside (X-gal, obtained from Bachem) and $0.3 \mathrm{~mm}$ isopropyl $\beta$-D-galactopyranoside (IPTG, from Bachem). Blue colonies containing the lacz promoter and operator regions were picked (Messing, 1983), and plasmid DNA was isolated by the alkaline lysis method (Birnboim and Doly, 1979; Maniatis et al., 1982). pTK501 plasmid, which has a HindIII site in the laci gene instead of the original $P v u I I$ site in the pUC18 plasmid, was identified by appropriate restriction enzyme analyses.

Construction of a bovine caudate cDNA library. Poly(A) ${ }^{+}$mRNA from bovine caudate nuclei was used to construct a cDNA library using a modified Okayama-Berg procedure (Okayama and Berg, 1982). Briefly, $6 \mu \mathrm{g}$ of poly $(\mathrm{A})^{+}$RNA was used to direct first strand cDNA synthesis with the primer vector fragment and avian myeloblastosis virus reverse transcriptase (Life Sciences). After addition of a (dC)-tail by terminal 


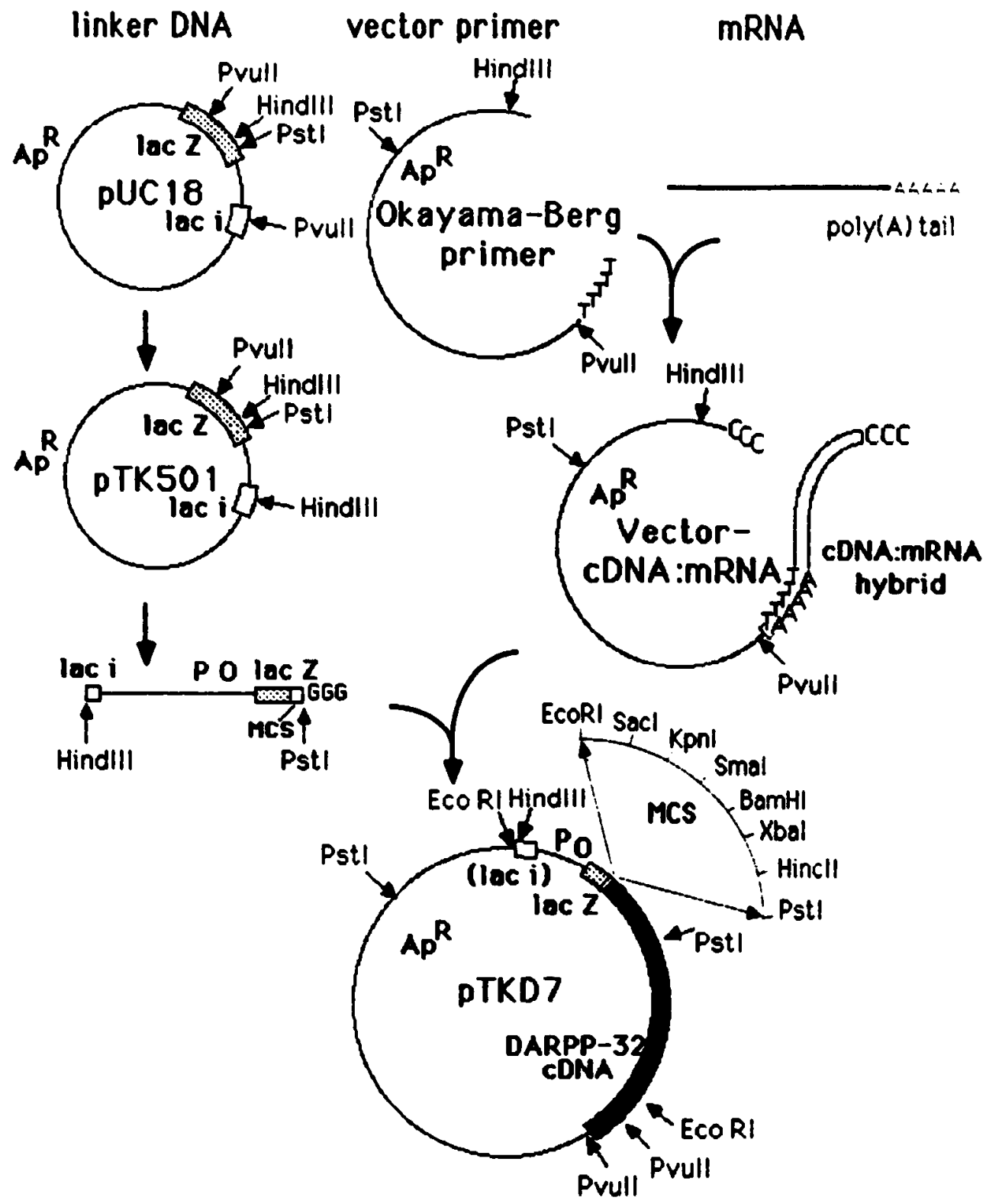

Figure 1. Construction scheme of the recombinant cDNA plasmid pTKD7. Details of the procedures and conditions are described in Materials and Methods and Results. $A p^{R}$, ampicillin-resistant gene; $M C S$, multiple cloning site.

deoxytransferase (Pharmacia), a novel oligo(dG)-tailed HindIII linker DNA fragment derived from pTK501 was inserted into the cDNARNA hybrid to produce a circular molecule (Fig. 1). Replacement of the RNA strand with DNA was accomplished by $E$. coli ligase (Pharmacia), $E$. coli DNA polymerase I (New England Biolabs), and $E$. coli $\mathrm{RNaseH}$ (Pharmacia) as described in the Okayama-Berg procedure. The cDNA/vector products constructed by this method were used to transform the WA802 strain of $E$. coli.

Preparation of oligonucleotide hybridization probes. Two oligonucleotide probes (oligo TK1 and oligo TK2 in Fig. 2) were prepared with the DNA Synthesizer 308A (Applied Biosystems) and purified by Sephadex G-100 (Pharmacia) column chromatography in TEAB buffer ( 10 mM triethyl amine bicarbonate, $\mathrm{pH} 8.5$ ). Oligonucleotides were labeled at the 5'-end with [ $\left.\gamma-{ }^{32} \mathrm{P}\right] \mathrm{ATP}$ using T4 polynucleotide kinase, followed by purification using Sephadex G-50 (Pharmacia) column chromatography. The specific activities of these probes were $>10^{8} \mathrm{cpm} / \mu \mathrm{g}$ DNA.

Colony hybridization. Colonies derived from the library were screened at a density of 2500 colonies $/ 82 \mathrm{~mm}$ petri dish. The DNA from lysed bacteria was transferred to nitrocellulose filters as described by Maniatis et al. (1982) and Grunstein and Hogness (1975) with the following modifications. The filters were first prehybridized in $3 \times \operatorname{SSC}(0.15 \mathrm{M}$ $\mathrm{NaCl}$ and $0.015 \mathrm{M}$ sodium citrate) for $30 \mathrm{~min}$ at $65^{\circ} \mathrm{C}$, then in $3 \times \mathrm{SSC}$, $10 \times$ Denhardt's solution $(0.02 \%$ Ficoll $400,0.02 \%$ polyvinyl pyrrolidone, $0.02 \% \mathrm{BSA}$ ) for $30 \mathrm{~min}$ at $65^{\circ} \mathrm{C}$, and finally in $1 \mathrm{M} \mathrm{NaCl}, 50 \mathrm{mM}$ Tris-HCl, pH 7.5, 10 mm EDTA, 0.1\% SDS, $10 \times$ Denhardt's solution, $10 \mu \mathrm{g} / \mathrm{ml}$ salmon testis DNA for $30 \mathrm{~min}$ at $65^{\circ} \mathrm{C}$. Hybridization was carried out in $1 \mathrm{~m} \mathrm{NaCl}, 50 \mathrm{~mm}$ Tris- $\mathrm{HCl}, \mathrm{pH} 7.5,10 \mathrm{~mm}$ EDTA, $0.1 \%$ SDS, $10 \times$ Denhardt's solution, $100-200 \mu \mathrm{g} / \mathrm{ml}$ salmon testis DNA with ${ }^{32} \mathrm{P}$ end-labeled synthetic oligonucleotides $\left(10^{5} \mathrm{cpm} / \mathrm{ml}, 2 \mathrm{ml} / \mathrm{filter}\right)$ for $15-24 \mathrm{hr}$ at $65^{\circ} \mathrm{C}$. Filters were washed at $65^{\circ} \mathrm{C}$ in $2 \times \mathrm{SSC}, 0.1 \%$ SDS, followed by $1 \times \mathrm{SSC}, 0.1 \% \mathrm{SDS}$, and then twice at $65^{\circ} \mathrm{C}$ in $0.2 \times \mathrm{SSC}$, $0.1 \%$ SDS for $30 \mathrm{~min}$ per wash, dried at room temperature, and subjected to autoradiography. Positive colonies were purified by 2 successive screenings.

Southern blot analysis. Southern hybridization (Southern, 1975) was used with the oligonucleotides as probes to analyze the putative positive clones. Cloned cDNAs ( $1 \mu \mathrm{g}$ per lane) cut with restriction endonucleases, size-fractionated on $1 \%$ agarose mini gels, and blotted onto nitrocellulose filters were hybridized to ${ }^{32} \mathrm{P}$-labeled probes. In the case of Southern blot analysis of genomic DNA (Fig. 6), $10 \mu \mathrm{g}$ each of bovine caudate 
DNA, following cleavage with individual restriction endonucleases, were hybridized with ${ }^{32}$ P-labeled antisense RNA (see below) and washed as detailed in the figure legends.

Detection of DARPP-32 cDNA clones with antibodies. Bacterial colonies were grown for $9 \mathrm{hr}$ at $37^{\circ} \mathrm{C}$ on LB plates supplemented with 50 $\mu \mathrm{g} / \mathrm{ml}$ ampicillin. Fusion protein production with $\beta$-galactosidase in the bacterial colonies transferred to nitrocellulose filters was induced with $50 \mu \mathrm{g} / \mathrm{ml}$ ampicillin and $0.2 \mathrm{mM}$ IPTG for $9 \mathrm{hr}$ at $37^{\circ} \mathrm{C}$. Filters were processed according to the procedure of Helfman et al. (1983) with the following modifications. Each filter was incubated in a separate dish, first with a mixture of mouse anti-DARPP-32 monoclonal antibodies [C24-4D7 and C24-5a (Hemmings and Greengard, 1986) preadsorbed with bacterial lysate] in blocking solution [5 mM Tris- $\mathrm{HCl}, \mathrm{pH} 7.5,15$ $\mathrm{mm} \mathrm{NaCl,} \mathrm{3 \%} \mathrm{BSA} \mathrm{(Sigma} \mathrm{fraction} \mathrm{V),} \mathrm{and} \mathrm{0.1 \%} \mathrm{Triton} \mathrm{X100]} \mathrm{for} 14$ hr at room temperature, and then with $1 \mu \mathrm{Ci}$ of goat anti-mouse ${ }^{125} \mathrm{I}$ Igs (specific activity, $8.8 \mu \mathrm{Ci} / \mu \mathrm{g}$ ) in blocking solution at room temperature for $2 \mathrm{hr}$.

Subcloning and sequencing of $c D N A$ fragments. Restriction fragments of pTKD7 were inserted into the appropriate sites in M13 $\mathrm{mp} 8, \mathrm{mp} 9$, mpl0, mpl1, and mp18 phages (Pharmacia), and the sequences were determined by the dideoxy method (Sanger et al., 1977; Messing, 1983).

Preparation of RNA probe. DARPP-32 antisense RNA probes were used for Northern and Southern blot hybridizations. The antisense probe was synthesized with SP6-polymerase according to Melton et al. (1984) using the pTKD7G3 plasmid, consisting of a 1667 base pair Bam HI/ $P v u I I$ DNA fragment from the pTKD7 clone subcloned into the $B a m \mathrm{HI} /$ HincII sites of pGEM3 (Promega Biotec). This template contains the entire cDNA region except a 170 base pair $P v u I I$ DNA fragment at the 3 '-end containing the poly(A) stretch of the clone. Following linearization of pTKD7G3 with $B a m H I$, the antisense RNA was synthesized according to Melton et al. (1984). The sense RNA (1715 nucleotides) was synthesized by using T7 RNA polymerase with $H$ indIIIlinearized pTKD7G3.

$R N A$ blot analysis. $\operatorname{Poly}(\mathrm{A})^{+}$and poly $(\mathrm{A})^{-}$RNA fractions were stored in $50-75 \%$ ethanol and lyophilized immediately before use. RNA blots were done essentially according to Maniatis et al. (1982) and Thomas (1980). The RNAs were transferred onto a nitrocellulose filter with $20 \times$ SSC to prepare the RNA blot. Hybridization procedures were essentially the same as described for the Southern hybridization procedure, except that the incubation was carried out in a mixture containing $50 \%$ formamide at $45^{\circ} \mathrm{C}$, with $200 \mu \mathrm{g} / \mathrm{ml}$ yeast tRNA, and the filter was washed at $60^{\circ} \mathrm{C}$ without formamide. Antisense riboprobe $\left(1 \times 10^{7} \mathrm{cpm} / \mathrm{ml}\right)$ derived from pTKD7G3 was used for hybridization. Quantitative autoradiography was performed using a Soft Laser Scanning Densitometer, model SL-TRFF (Biomed Instruments, Inc.). The filter was stained with methylene blue (15 min in $5 \% \mathrm{HOAc}, 10 \mathrm{~min}$ in $0.04 \%$ methylene blue, $0.5 \mathrm{M} \mathrm{NaOAc}$, then $\mathrm{H}_{2} \mathrm{O}$ ) to visualize the ribosomal RNA bands (Maniatis et al., 1982; Zinn et al., 1983). Calf liver 28S rRNA (4.7 kb) and $18 \mathrm{~S}$ rRNA (1.9 kb) were used as standards (Pharmacia).

Other enzymes and reagents. $E$. coli DNA polymerase I (Kenow fragment), RNasin (RNase inhibitor) from human placenta, ribo-, deoxy-, and dideoxy-nucleotide triphosphates, HindIII linker, and DNA size marker, DRIgest III were purchased from Pharmacia. T4 DNA ligase, terminal deoxytransferase, $E$. coli polynucleotide kinase and restriction endonucleases were purchased from Boehringer Mannheim, Bethesda Research Laboratorics, New England Biolabs, or Pharmacia. $\gamma$ - ${ }^{32} \mathrm{P}$-dATP $(3000 \mathrm{Ci} / \mathrm{mmol}), \alpha-{ }^{32} \mathrm{P}-\mathrm{rCTP}(800 \mathrm{Ci} / \mathrm{mmol}), \alpha-{ }^{35} \mathrm{~S}-\mathrm{dATP}$ $(500 \mathrm{Ci} / \mathrm{mmol})$, and ${ }^{125} \mathrm{I}$-goat anti-mouse Igs $(8.8 \mu \mathrm{Ci} / \mu \mathrm{g})$ were from New England Nuclear. Monoclonal antibodies to bovine DARPP-32 were kindly provided by Dr. Hugh C. Hemmings, Jr. of this laboratory. Other chemicals were obtained from standard commercial suppliers.

\section{Results}

Construction of the Okayama-Berg expression system

A novel method was used to clone the cDNA for this protein, which was the development of a modified Okayama-Berg expression cloning vector (Fig. 1). The Okayama-Berg vector is derived from 2 different DNA fragments, a poly(T)-tailed vector-primer DNA and an oligo(dG)-tailed linker DNA, and has the potential capability to be an expression vector (Okayama and Berg, 1982). As a linker DNA fragment, we chose an $E$. coli lactose gene fragment, which carries a promoter, an operator, the $N$-terminus of $\beta$-galactosidase, and the M13 multiplc cloning sites (MCS) from EcoRI to PstI, immediately followed by oligo(dG). This fragment was constructed from pTK501, which was derived from pUC18 as described in Materials and Methods. The new Okayama-Berg expression vector has several advantages over the standard method, including (1) inducible expression within a host carrying the $\mathrm{laci}^{+}$or $\mathrm{laci}^{\mathrm{Q}}$ gene, (2) the predetermined orientation of the forcign gene in the same direction as the lac gene, since the poly(A) tail of the mRNA is attached to the opposite end of the vector-primer DNA carrying the poly(T) tail, (3) convenient polylinker sites for subcloning, and, finally (4) the ability to sequence the 5 '-end of the insert DNA directly by using an M13 reverse sequence primer. Although proper expression of foreign DNA will depend on the reading frame of the DNA insert with respect to that of $\beta$-galactosidase, the potential flexibility of the length of the $\mathrm{dG}$ tail of the linker DNA fragment and of the $\mathrm{dC}$ tail of the 5 '-end of the cDNA will increase the likelihood of correct joining. Finally, sequential use of the screening systems should decrease the number of false-positive clones obtained by the use of any single method alone.

\section{Isolation of a cDNA clone for DARPP-32 $\mathrm{mRNA}$}

Starting with $0.5 \mu \mathrm{g}$ of poly(A)+ RNA from bovine caudate nuclei, a cDNA library of $1.0 \times 10^{5}$ clones was constructed using the Okayama-Berg procedure (Fig. 1). The library was screened by the colony hybridization method (Grunstein and Hogness, 1975; Maniatis et al., 1982) using 2 different oligonucleotide probes (oligo TK1 and oligo TK2). These oligonucleotides were designed on the basis of the amino acid sequence of bovine DARPP-32 (Williams et al., 1986), which contains an unusual stretch of acidic residues (amino acid residues 119134). We chose this Glu-rich region for synthesis of two 47 mer-oligonucleotide hybridization probes. One of them, oligo TK2, contains all possible codons, with a mixture of $2^{15}$ possible species of the nonsense strand. The other probe, oligo TKI, was synthesized on the basis of the following criteria. The mammalian codon usage data (Grantham et al., 1981) indicate that about $60 \%$ of the Glu codon is GAG, while the remaining $40 \%$ is GAA. In addition, we know that $G$ residues may be bound not only to $\mathrm{C}$ residues (by Watson-Crick base pairing) but also to $\mathrm{T}$ residues (by the wobble theory proposed by Crick, 1966), and that $\mathrm{G}: \mathrm{C}$ base pairing is thermodynamically more stable than A:T base pairing. Therefore, we chose the GAG codon or the CTC anticodon as glutamic acid and the sense strand instead of the nonsense strand. The number of species for oligo TK1 is only 2 , which is derived from the combination of 2 possible codons for the ${ }^{128} \mathrm{Asp}$ residue (GAT or GAC). The amino acid sequences and the corresponding oligonucleotide probes are summarized in Figure 2.

We hybridized oligo TK1 and oligo TK2 in parallel against identical replica filters to screen the library (approximately $4.75 \times$ $10^{4}$ recombinant colonies). Some positive signals were detected only by one of the 2 probes, while others were detected by both probes. Ten colonies (pTKD1-10) detected by both probes were selected. To verify the identity of these 10 clones, restriction enzyme analyses and Southern hybridization with the oligo TK1 were performed in order to look for a similar restriction pattern. Double restriction digests with $P s t \mathrm{I} / P v u \mathrm{II}$ and $P s t \mathrm{I} / E c o \mathrm{RI}$ gave restriction fragments of 1.0 and $0.17 \mathrm{~kb}(P s t \mathrm{I} / P v u \mathrm{II})$ and $0.8 \mathrm{~kb}$ (Pst I/EcoRI) for 4 clones: pTK 1, 3, 7, and 8. In addition, Southern blot analysis showed that both the $1.0 \mathrm{~kb}$ fragment and the $0.8 \mathrm{~kb}$ fragment hybridized with the oligo TK1 (Fig. 3). 


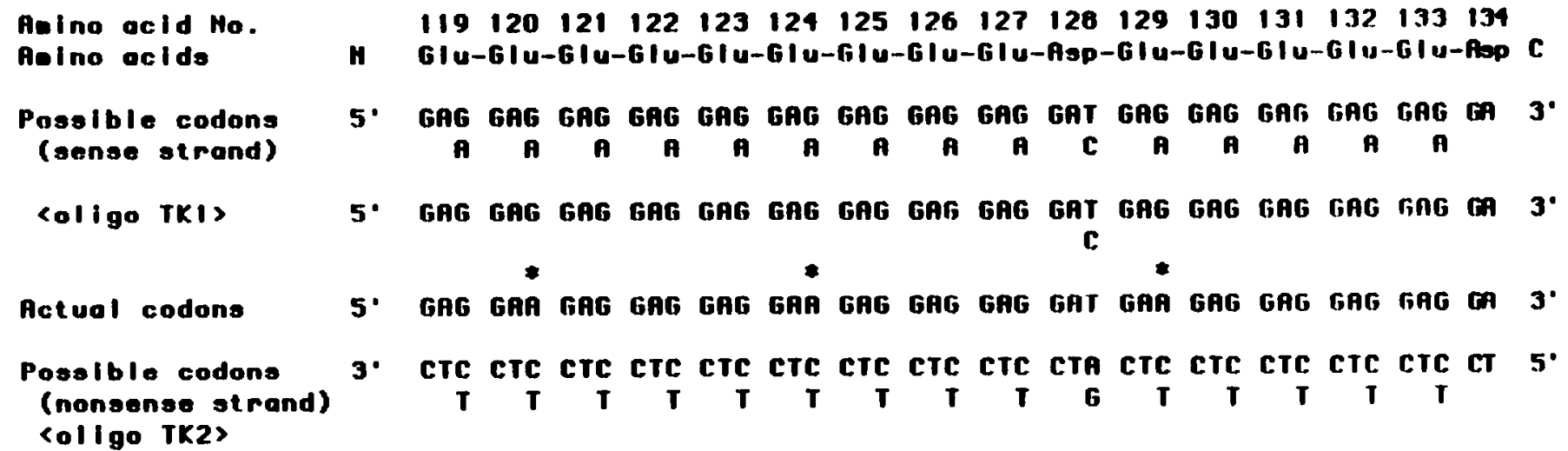

Figure 2. Synthetic oligonucleotide DNA probes used for screening of bovine DARPP-32 clones. Possible nucleotide sequences, either sense or nonsense strand, deduced from the amino acid sequence (119-134) of purified DARPP-32 from bovine caudate (Williams et al., 1986) are shown. Oligo TK 2 was constructed from a mixture of all nonsense strands with possible codons. Oligo TK1 was made up of 2 species of sense strands. Actual nucleotide sequence is shown as a sense strand, which was derived from the DNA sequence of cDNA clone pTKD7. Three asterisks indicate differences in nucleotides between oligo TK1 and actual DNA sequences.

\section{Immunological analysis}

Since the Okayama-Berg vector (pSV7186) used in these studies was supplemented with the $E$. coli lac $z$ from the pTK501 (Fig. 1), these 4 clones could be further analyzed via expression of their cDNA fusion proteins. By in situ immunoassay with mouse anti-DARPP-32 monoclonal antibodies (mixture of C24-4D7 and C24-5a; Hemmings and Greengard, 1986), only clones pTKD3, 7 , and 8 gave positive signals among the 10 putative positive clones (data not shown). Using both in situ colony hybridization and in situ immunoassay to screen the library, we concluded at this point that clones pTKD3, 7, and 8 were cDNAs coding for DARPP-32 mRNA.

\section{Identification of DARPP-32 cDNA by nucleotide sequencing}

Clones pTKD3, 7, and 8 had a $0.8 \mathrm{~kb} P s t / / E c o$ RI restriction fragment that hybridized with oligonucleotide probe TK1 (Fig. 3 ). These $0.8 \mathrm{~kb}$ Pst $\mathrm{I} / E c o \mathrm{RI}$ fragments were individually subcloned into the Pst $/$ HincII sites of M13 phage vectors mp10 and mpl 1 (Messing, 1983) and sequenced from both ends by the dideoxy chain termination sequencing method (Sanger et al., 1977). The nucleotide sequences of these 3 fragments were identical, and the 130 bases sequenced from the Pst I site revealed a deduced amino acid sequence that was identical with the experimentally established amino acid sequence of bovine DARPP-32. A restriction map analysis and the sequencing strategy of the longest clone pTKD7 is presented in Figure 3. The complete base sequence and deduced amino acid sequence of clone pTKD7 is shown in Figure 4. The sequence data indicate that pTKD7 is 1771 nucleotides in length. It contains the complete coding sequence corresponding to the bovine DARPP-32 protein, coding for 202 amino acids, including the initiation codon ATG and the termination codon TAG (amber). There are 341 nucleotides of $5^{\prime}$ noncoding region and 824 nucleotides of $3^{\prime}$ noncoding region. There are 2 potential polyadenylation signals, as the sequence AATAAA (Proudfoot and Brownlee, 1976 ) is present immediately upstream and 11 nucleotides upstream from the start of the poly(A) tail, which contains 80 nucleotides of A residues. DNA sequence analyses also showed that oligo TK1 contained a sequence almost homologous to DARPP-32 mRNA, i.e., 11 out of 14 Glu codons were GAG (Fig. 2). The codon usage ratio of GAG to GAA for Glu is actually about $80 \%$ to $20 \%$ in this region. Oligo TK1 gave a stronger signal than oligo TK2 in the case of Southern blot hybridization with restriction DNA fragments of these clones (data not shown), probably because of the difference of the hybridization stability between the 2 probes and cDNAs.

\section{$m R N A$ analyses by blot hybridization}

The cDNA (pTKD7) was subcloned in reverse orientation into the vector pGEM3 downstream of the SP6 promoter to construct a pTKD7G3. The DARPP-32 antisense RNA was synthesized in vitro with $\alpha-{ }^{32} \mathrm{P}-\mathrm{rCTP}$ and the pTKD7G3 as template, and then used as a hybridization probe to poly $(\mathrm{A})^{+} \mathrm{RNA}$ or poly(A) ${ }^{-}$RNA from bovine caudate to identify the DARPP32 mRNA. The antisense RNA hybridized with 2 poly $(\mathrm{A})^{+}$ RNA species of 1.8 and $1.65 \mathrm{~kb}$ (Fig. 5, lane 1). At least 3 faint bands were detected in the poly(A)- RNA preparation in this
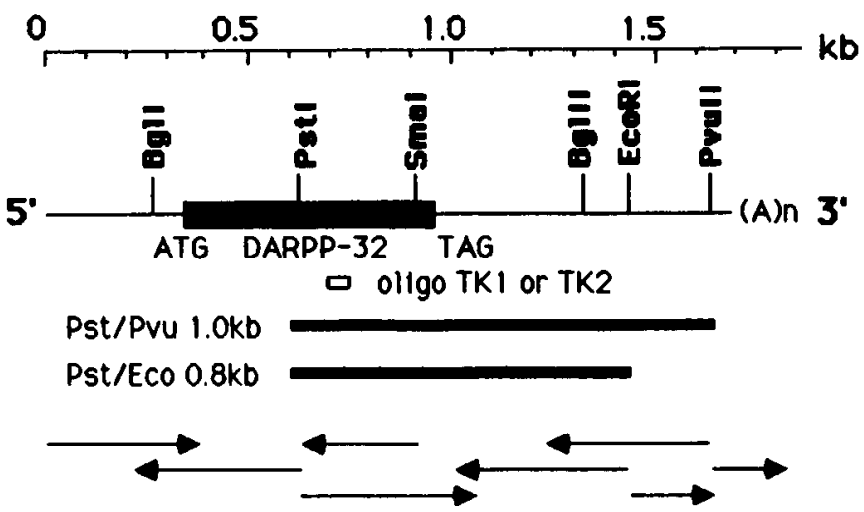

Figure 3. Restriction map and sequencing strategy of the cDNA of clone pTKD7. The scale above the restriction map indicates the nucleotide positions in kilobases $(\mathrm{kb})$ relative to the first nucleotide in the cDNA pTKD7, which is just after the $15 \mathrm{G}$ residues. The thick black line depicts the coding region for DARPP-32 protein, while the thin lines depict the $5^{\prime}$ and $3^{\prime}$ untranslated regions of the mRNA. Translation start codon (ATG), translation stop codon (TAG), and poly(A) tail [(A)n] are also shown. Two black bars represent the restriction fragments that hybridize with one or both synthetic oligomers, oligo TK1 and oligo TK2, which correspond to the open box. The arrows indicate the direction and extent of DNA sequence that was determined by the dideoxy chain termination sequencing method (Sanger et al., 1977) using bacteriophage M13 subclones as templates and M13 general sequence primer (Messing, 1983). 


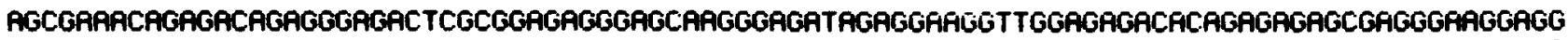
$\begin{array}{ccccccc}10 & 20 & 30 & 40 & 50 & 60 & 70\end{array}$

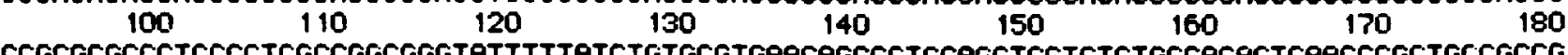
CCGCGCGCCCTCCCCTCGCCGGCGGGTATTTTTATCTGTGCGTGAACAGCCCTCCAGCTCCTCTCTGCCACACTCAACCCGCTGCCGCCG $\begin{array}{llllllll}190 & 200 & 210 & 220 & 230 & 240 & 250 & 260\end{array}$

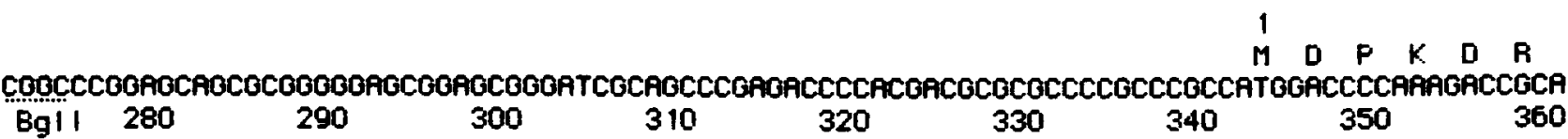

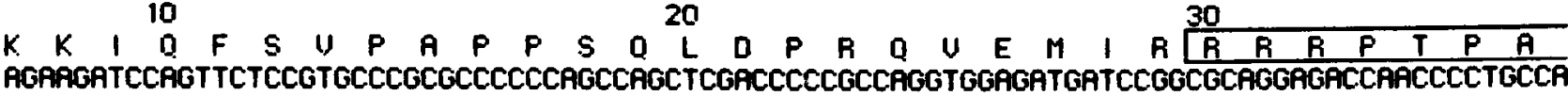
$\begin{array}{llllllll}370 & 380 & 390 & 400 & 410 & 420 & 430 & 440\end{array}$

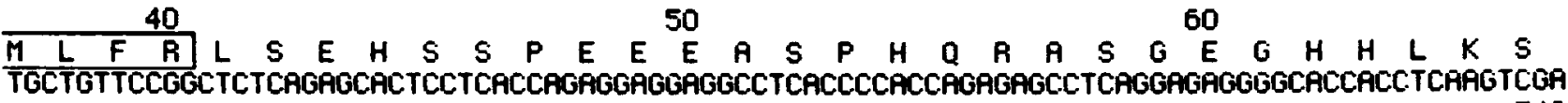
$\begin{array}{llllllll}460 & 470 & 480 & 490 & 500 & 510 & 520 & 530\end{array}$

$70 \quad 80 \quad 90$

$\begin{array}{llllllllllllllllllllllllllllllllll}K & R & S & N & P & C & A & Y & T & P & F & S & L & K & A & U & Q & A & 1 & A & E & S & H & L & Q & S & 1 & S & N & L\end{array}$ AGAGATCCAATCCTTGTGCCTACACACCCC.CCTCGCTGARAGCCGTCCAGCGCATTGCTGAGTCTCACCTGCAGTCCATCAGCARCCTGG

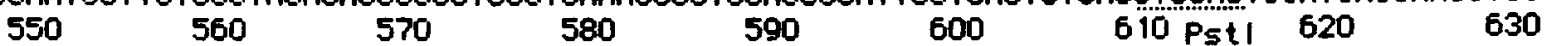

$100 \quad 110 \quad 120$

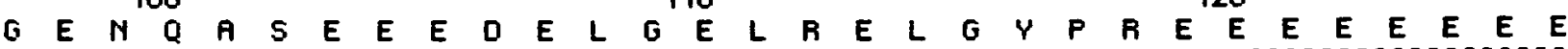

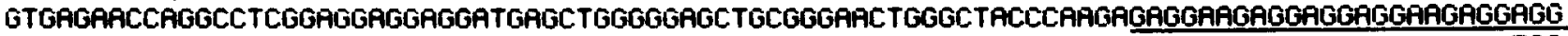

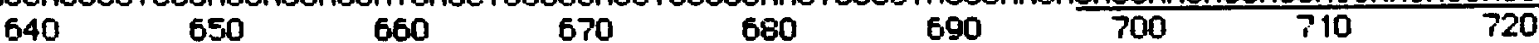
$130140 \quad 150$

E D D E

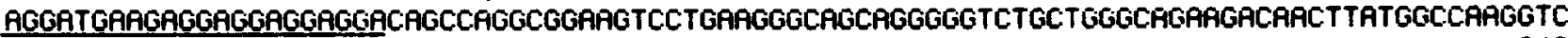

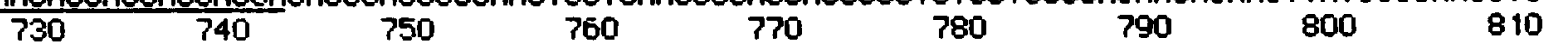

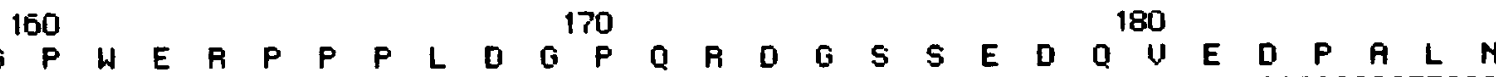

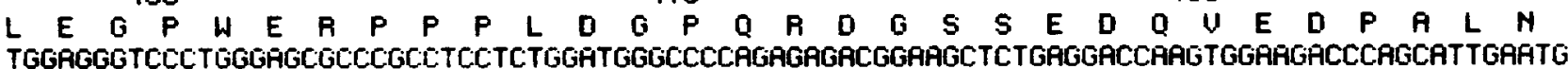
$\begin{array}{lllllllll}820 & 830 & 840 & 850 & 860 & 870 & 880 & 890 & 900\end{array}$ 190

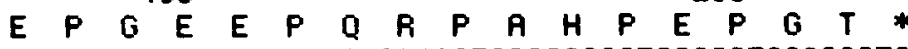

ARCCCGGGGAGGFGCCACAGCGCCCTGCCCACCCTGAGCCTGGCACATAGGCACCCAGCCCTGCATCTCCTGGAAGGAAGTGGGAGGARG

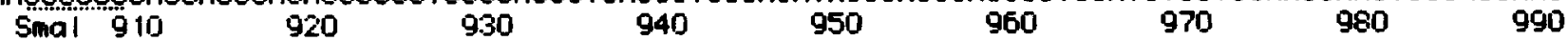
CATTGATGTTCTCCAGARACCCATTCTGTTCACACCCTATTTTGTACCC.TGCTTC:TCACTTGCTAGGGCTGCGGCTTCTGACTTTTAGAR

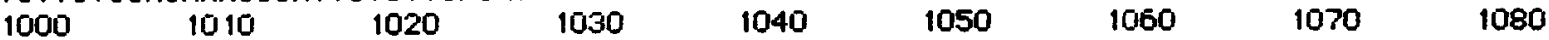
GACTAAGGCTGGTCTGTGTTTGCTTGTCTGCCCAACTTCGCTGATCCCAGAGTCC. TGGGCACTTGCTGCCTGATGCCTACCCCTGCCAG $\begin{array}{llllllll}1090 & 1100 & 1110 & 1120 & 1130 & 1140 & 1150 & 1160\end{array}$

TCATTCCCCCATACACLORLCAGGAGGTGGGATGGGAGAGCTTGCATTGGGAAATCCAGTAAATGGGGGACARAGATTCATCCTTCACAA

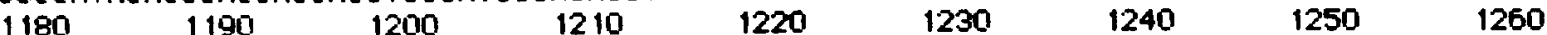

TTCTACTCC.TAGACC.TCTCCCCTGGGCGTAGGAAACCACAGGGCAGGACC.CTARGATC.TGGGGAARAGGGATACTGAGAACTTGTARG $\begin{array}{llllllll}1270 & 1280 & 1290 & 1300 & 1310 & 1320 \mathrm{Bg} / 1 / 1330 & 1340 & 1350\end{array}$

TGCCCATAGATC:TTTCTCCATCCCCTGGGCAATTCCAAGTCATCACCCCTTCACTGCCTTCTACCAGGGCC.CAGAATTCAGGCATCTTTT $\begin{array}{llllllll}1360 & 1370 & 1380 & 1390 & 1400 & 1410 & 1420 \text { ECORI 1430 } & 1440\end{array}$

CCACGGCCTCAGCTTTTGGTARATCTTCCCCTTATCACCTGCTCCCCAGCCTGGGTGCCTGGAAGATGGACTGGCAGAGRCTGCTTTGCT $\begin{array}{llllllll}1450 & 1460 & 1470 & 1480 & 1490 & 1500 & 1510 & 1520\end{array}$

GCATTTTATGTGTGCTTTGATGCCAGGAATGCCACCTAGTATAATARGTCCTTAGGGGGGCACHTGGTGGGGGAGCCARGCTCTCCTTGT

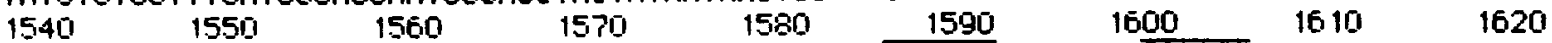

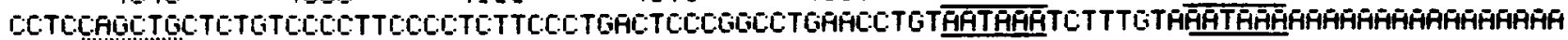

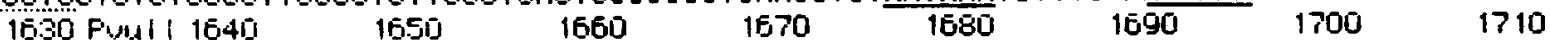

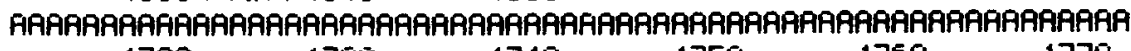
$\begin{array}{llllll}1720 & 1730 & 1740 & 1750 & 1760 & 1770\end{array}$

Figure 4. Complete nucleotide sequence of pTKD7 and the amino acid sequence of bovine DARPP-32 cDNA encoded therein. The numbering of the nucleotides (below sequence) starts at the first nucleotide after the string of Gs and ends at the 80 adenine residues in the $3^{\prime}$ poly(A) tail. Amino acid residues are numbered (above sequence) by the position of 1 for the Met residue of the predicted amino acid sequence of the protein. The nucleotide sequence (47 residues) used to generate the synthetic oligonucleotide probes (oligo TIK1 and oligo TK2) is indicated by a single solid underline. Potential polyadenylation signals in the $3^{\prime}$ untranslated region are indicated by overlines and underlines. The recognition sites for restriction enzymes shown in Figure 3 are presented with dotted underlines. The amino acid sequence around the Thr residue phosphorylatable in vitro is enclosed in the box. 
blot (lane 2). These bands were also detected in the poly $(\mathrm{A})^{+}$ preparation (lane 1), probably due to contamination by poly(A)RNA. Two of these bands appear to correspond to the rRNA bands (28S and $18 \mathrm{~S}$ ), since we observe that the rRNAs themselves tend to cross-hybridize to the DARPP-32 antisense RNA (data not shown). Nevertheless, the predominant bands (1.8 and $1.65 \mathrm{~kb}$ bands in lane 1) were considered to be highly specific to the DARPP-32 antisense RNA, since only these 2 bands, but not others, remained under even more stringent washing conditions with RNase A (data not shown).

\section{Southern blot analysis of bovine genomic DARPP-32}

In order to investigate the genomic organization, chromosomal DNA from bovine caudate was analyzed using DARPP-32 antisense RNA as a probe followed by washing under stringent conditions [0.1 $\times$ SSC, $0.1 \%$ SDS for $30 \mathrm{~min}$ at $65^{\circ} \mathrm{C}$ (Fig. 6)]. Single digestion with EcoRI (lane 1), HindIII (lane 3), BamHI (lane 5), Pst I (lane 9), or PvuII (lane 11) gave bands of 1.4, 9.5, $21,2.5$, or $0.95 \mathrm{~kb}$, respectively. Double digestion with both EcoRI and either HindIII (lane 2), BamHI (lane 4), XhoI (lane 6), Pst I (lane 8), or PvuII (lane 10) gave bands of $0.84,1.4,1.4$, 1.4 , or $0.72 \mathrm{~kb}$, respectively. All combinations gave a single band. Therefore, it is unlikely that the genome coding for DARPP-32 is present in greater than a single copy. Under less stringent conditions $\left(0.2 \times \mathrm{SSC}, 0.1 \% \mathrm{SDS}\right.$ for $30 \mathrm{~min}$ at $60^{\circ} \mathrm{C}$ as a final washing), however, EcoRI gave an extra band of 1.6 $\mathrm{kb}$ in addition to the band of $1.4 \mathrm{~kb}$, and Pst $\mathrm{I}$ gave 2 bands of 2.45 and $2.55 \mathrm{~kb}$ instead of the single band of about $2.5 \mathrm{~kb}$ (data not shown). Since the antisense RNA contains a single restriction site for EcoRI or Pst I, it can be concluded that 2 restriction fragments of a single genomic DNA were hybridized to the antisense RNA (Fig. 3). Double digestion studies (Fig. 6) also demonstrated that the $1.4 \mathrm{~kb} E c o$ RI fragment was within the BamHI, XhoI, or PstI fragment, and that at least one HindIII and one $P v u$ II site were present in the $1.4 \mathrm{~kb} E c o$ RI fragment. The HindIII site in the $1.4 \mathrm{~kb} E c o$ RI fragment in the genomic DNA was not detected in the 1424 bp fragment of the cDNA. Furthermore, there is only one PvuII site within the cDNA, which is at the $3^{\prime}$ end of the antisense probe, and the $0.72 \mathrm{~kb}$ $P v u$ II fragment of the genomic DNA cannot exist in the antisense RNA region of 1627 nucleotides. Either analysis of the double digestion studies indicates that at least one intron is present in the genome of bovine DARPP-32.

\section{Distribution of DARPP-32 $\mathrm{mRNA}$ in bovine CNS and rat tissues}

The distribution of DARPP-32 mRNA was studied in 6 separate regions of bovine CNS by using the DARPP-32 antisense RNA (Fig. 7, lanes 1-6). Forty micrograms of total RNA were analyzed by Northern blot hybridization as described in Materials and Methods and the legend to Figure 5. DARPP-32 mRNA was found to be highly enriched in the caudate nucleus, which is in agreement with the enrichment of the protein in this region (Ouimet et al., 1984; Walaas and Greengard, 1984; Hemmings and Greengard, 1986). Lower, but still significant, levels were demonstrated in the hippocampus, cerebellum, and medulla white matter. These levels were approximately $1-2 \%$ of that of caudate nucleus. Cerebral cortex contained the mRNA at slightly higher concentrations than these areas, i.e., at about $3 \%$ of that of caudate nucleus. In the substantia nigra the level of DARPP-32 protein, as measured by immunoprecipitation and Western blot analyses (J.-A. Girault, personal communication),

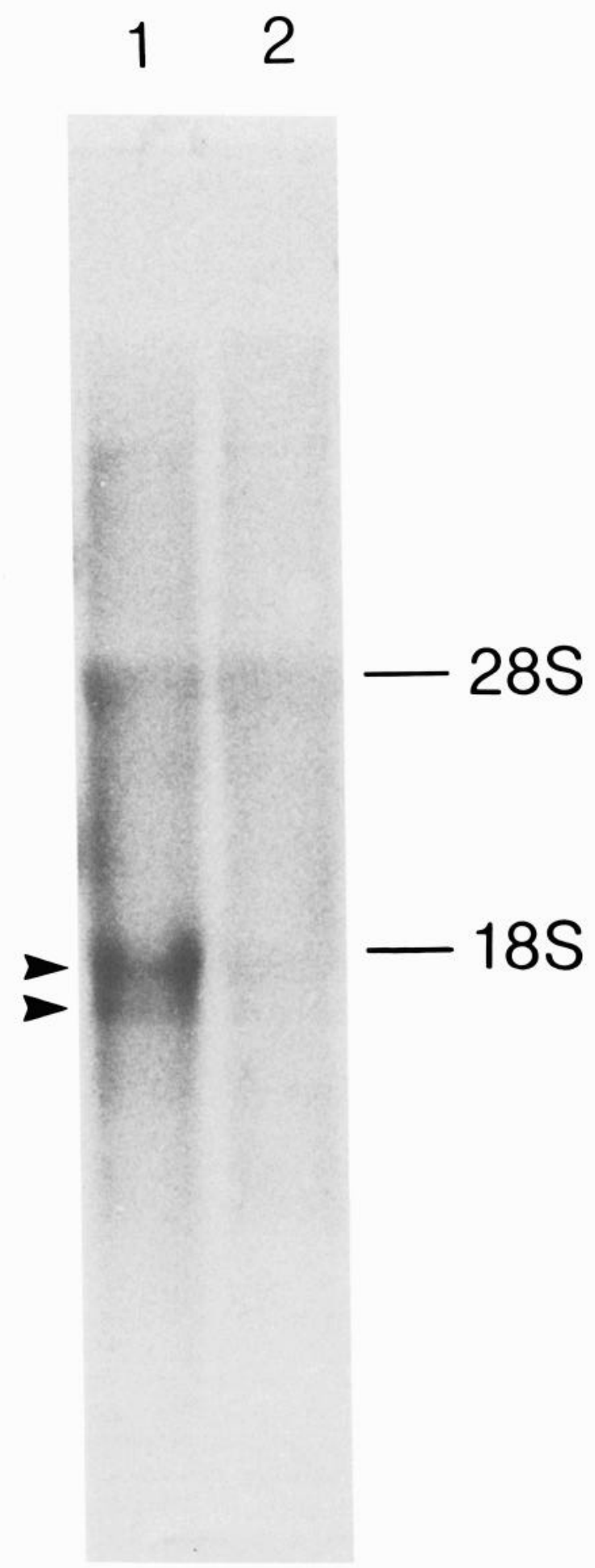

Figure 5. Northern blot analysis of poly(A)+ RNA from bovine caudate nucleus. Twenty micrograms of poly(A)+ RNA (lane 1 ) and poly(A)RNA (lane 2) were separated in a $1.2 \%$ agarose gel containing $2.2 \mathrm{M}$ formaldehyde. After transferring to nitrocellulose, they were hybridized to a ${ }^{32} \mathrm{P}$-labeled antisense RNA probe derived from pTKD7G3 as template. Sizes of the bands (1.8 and $1.65 \mathrm{~kb})$ marked by arrowheads in lane 1 were determined by rRNA markers.

is about half that of the caudate nucleus. The DARPP-32 mRNA level in the same region, however, was only $3 \%$ of that of caudate nucleus. The levels of DARPP-32 mRNA were also measured in the caudate nucleus and the liver from the rat (Fig. 7, lanes 


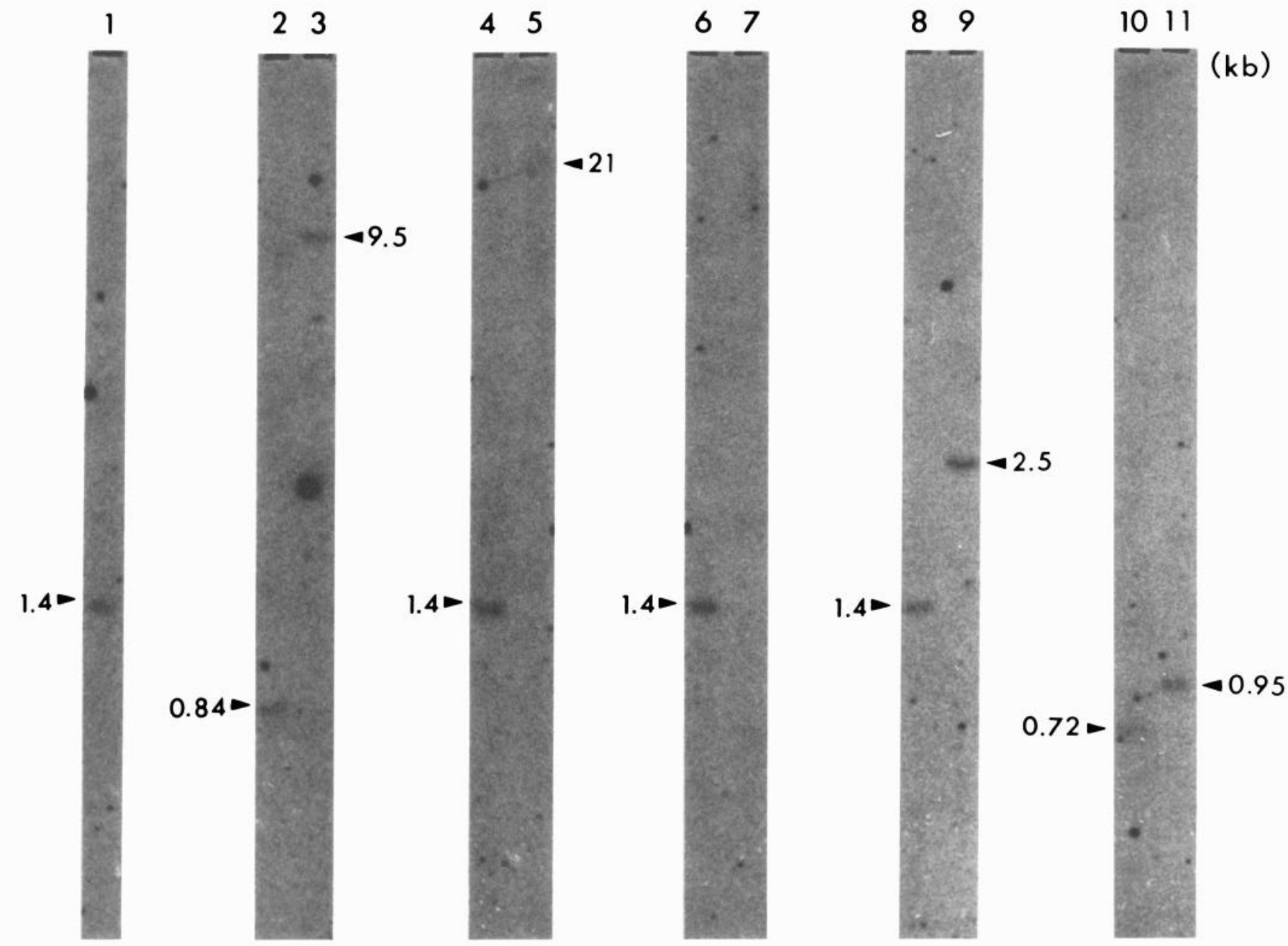

Figure 6. Southern blot analysis of genomic DNA. Ten micrograms of bovine caudate DNA were digested with restriction endonucleases, electrophoresed through a $0.9 \%$ agarose gel, transferred to a nitrocellulose filter, and hybridized with ${ }^{32} \mathrm{P}-$-labeled DARPP-32 antisense RNA as described in Materials and Methods. Stringent conditions were used for final washing $\left(0.1 \times \mathrm{SSC}, 0.1 \%\right.$ SDS for $30 \mathrm{~min}$ at $\left.65^{\circ} \mathrm{C}\right)$. Lane 1 , EcoRI; 2, EcoRI/HindIII; 3, HindIII; 4, EcoRI/BamHI; 5, BamHI; 6, EcoRI/XhoI; 7, XhoI; 8, EcoRI/PstI; 9, PstI; 10, EcoRI/PvuII; 11, PvuII. RNase was used for reduction of the background $(1 \mu \mathrm{g} / \mathrm{ml}$ R NaseA in $2 \times \mathrm{SSC}$ for $15 \mathrm{~min}$ at room temperature). Sizes were calculated from co-electrophoresis of DRIgest III (Pharmacia; mixture of both phage $\lambda c I^{857}$ Sam7 DNA digested with HindIII and $\phi$ X174DNA digested with HaeIII), and are indicated in kilobases.

7 and 8). No detectable band was observed in the rat liver, but a strongly positive band was detected in the rat caudate nucleus, although only $5 \%$ of that in bovine caudate nucleus. Although the efficiency of cross-hybridization between the rat and bovine species is unknown, only a single band was detectable, at least under these experimental conditions. The molecular size of the rat mRNA was slightly larger than that of the bovine mRNA. Using immunoprecipitation and Western blot analyses, rat DARPP-32 protein is immunoreactive with anti-bovine DARPP-32 monoclonal antibodies, but the molecular size of rat DARPP-32 protein is slightly larger than that of the bovine protein (Ouimet et al., 1984; Hemmings and Greengard, 1986).

\section{Discussion}

In this paper, we describe the cloning of a cDNA for bovine DARPP-32, a neuron-specific phosphoprotein. Our sequence data (Fig. 4) indicate that the longest clone, pTKD7, has 341 nucleotides before the Met codon, which corresponds to the amino terminal end of the DARPP-32 protein. Since this clone has 15 nucleotides of $\mathrm{G}$ residues between the PstI restriction site
[CTGCA $(G)$ ] and the cDNA insert, there are 414 nucleotides, corresponding to 138 amino acids, before the structural gene. There is also one termination codon (TAG) at the 41 st position from the $\beta$-galactosidase translation start codon in the same reading frame. The bacterial host harboring this plasmid is WA802 carrying supE44, which suppresses the TAG termination codon. This could potentially overcome the translation termination signal, or the translation could be reinitiated after the TAG codon. The second longest clones, pTKD3 and pTKD8, which also gave positive signals with in situ immunoassay, contained 118 nucleotides in the $5^{\prime}$ noncoding region and $10 \mathrm{nu}-$ cleotides of G residues after the PstI site. These clones have 62 amino acids before the structural gene of the DARPP-32. Although we did not sequence the coding region of the clone pTKD1, the restriction map indicated that it was very similar to that of the clones pTKD3 and pTKD8. Clone pTKD1, however, gave no positive signal in the in situ immunoassay, perhaps because it was out of phase with $\beta$-galactosidase.

The open reading frame sequence of 606 nucleotides starting with the Met codon at position 342 encodes a protein of 22,614 


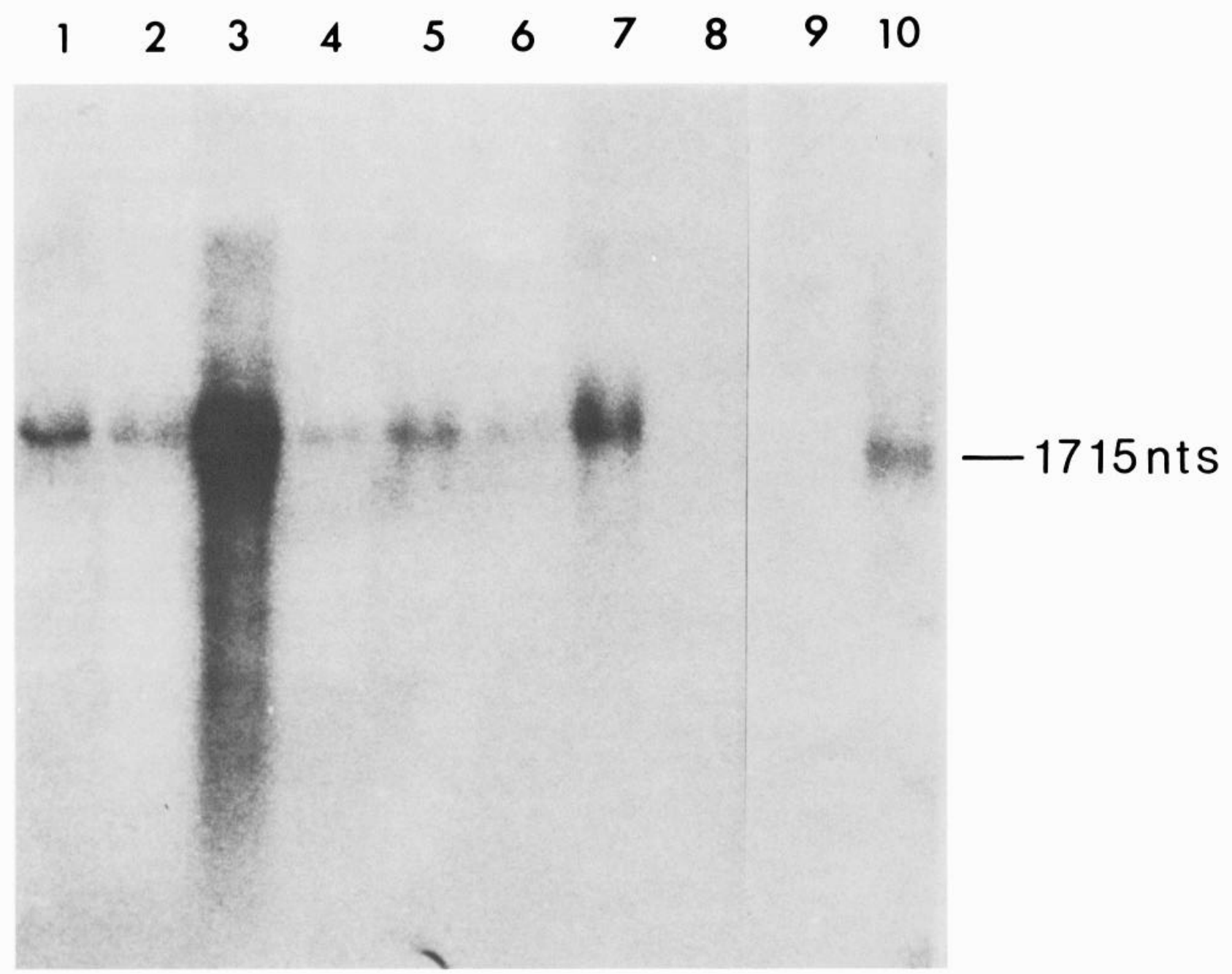

Figure 7. Regional distribution of DARPP-32 mRNA in bovine CNS and rat tissues by Northern blot analysis. Forty micrograms of total RNA were separated in a $1.0 \%$ agarose gel containing $2.2 \mathrm{M}$ formaldehyde and analyzed by Northern blot hybridization as described in the legend to Figure 5. Lanes 1-6 contained bovine cerebral cortex, hippocampus, caudate nucleus, cerebellum, substantia nigra, and medulla white matter; lanes 7 and 8 , rat caudate nucleus and liver. Lanes 9 and 10 contained about 2 and $20 \mathrm{pg}$ of in vitro synthesized bovine DARPP-32 mRNA [1715 nucleotides (nts)], which were prepared by using T7 RNA polymerase and HindIII-linearized pTKD7G3 as template.

$\mathrm{Da}$, with the exact amino acid sequence of the bovine DARPP32 protein. Although the amino terminal residue of this protein is blocked, and could not be identified by amino acid sequence analysis (Williams et al., 1986), we can conclude that the Met codon at position 342 corresponds to the first $\mathrm{N}$-terminal amino acid of DARPP-32 for the following reasons: (1) the codon at position 342 is the first Met codon in the open-reading frame sequence; (2) a typical consensus sequence (CC ${ }^{A} /{ }_{G} \mathrm{CCATGG)}$ around a translation initiation codon (Kozak, 1986) is present around the Met codon at position 342 (CCGCCATGG).

The amino acid sequence derived from the cDNA matched that of the protein. There are $37 \mathrm{Glu}, 13 \mathrm{Gln}, 10 \mathrm{Asp}$, and 4 Asn in the DARPP-32 protein, as well as in those derived from the corresponding codons, indicating that there is no amino acid change after the translation of this protein. The Thr codon, which is phosphorylated by cyclic AMP-dependent protein kinase in vitro, is present at position 441 .

RNA blot analysis of the bovine caudate demonstrated 2 homologous mRNAs of 1.8 and $1.65 \mathrm{~kb}$. The probe was the antisense RNA derived from the PstI/PvuII 1642 nucleotide sequence of the cDNA clone pTKD7, which does not contain the $P v u \mathrm{II}$ restriction fragment of 170 nucleotides at the $3^{\prime}$-end with the poly(A) tail. The clone pTKD7 may actually be derived from the $1.8 \mathrm{~kb}$ mRNA, as judged by the similarity of its size to that of the DARPP-32 mRNA visualized in Northern blots (Figs. 5 and 7). The fact that RNA blot hybridization revealed the presence of 2 DARPP-32 mRNA species suggests several possibilities. First, the 2 mRNAs may be derived from 2 different genes. Second, the 2 mRNAs may be derived from a single gene, with 2 different messages being produced by posttranscriptional modification. In the latter case, one would expect a different splicing pattern, a different polyadenylation site, such as is seen in dihydrofolate reductase (Setzer et al., 1980) and CaM mRNA species (Lagacé et al., 1983), or degradation of the 5 '-end and/or 3'-end. Third, it is possible that the $1.8 \mathrm{~kb}$ mRNA may be a nuclear precursor for the $1.65 \mathrm{~kb}$ mRNA. The larger mRNA is almost certainly not heterogeneous nuclear RNA, since it was as abundant as the smaller mRNA. Fourth, it is possible that one of the 2 mRNAs is the actual DARPP- 32 mRNA and that the other is an unrelated, but homologous, mRNA. Since the antisense RNA used as a probe for Northern hybridization contained not only the structural gene but also 
the $5^{\prime}$ and $3^{\prime}$ noncoding regions, this homology may exist either in the regulatory region or in the structural region. Phosphatase inhibitor- 1 is a candidate for the latter possibility, since there is amino acid sequence homology and immunological crossreactivity between them (Hemmings and Greengard, 1986; Williams et al., 1986). Further experiments are needed to distinguish among these possibilities.

Southern blot analysis of bovine caudate genomic DNA revealed that there were a small number of restriction fragments that hybridized to DARPP-32 antisense RNA (Fig. 6). Under stringent washing conditions, a single band was observed using several restriction enzymes. Figure 6 also shows the double digestion pattern using both $E c o$ RI and $H i n d I I I, B a m H I, X h o I$, PstI, or PvuII. All combinations gave a single band. Therefore, it can be concluded that the DARPP-32 gene is present in a single copy, ruling out the possibility that the 2 mRNA species are derived from different genes. Furthermore, the analyses of the double digestion studies revealed that the structure of the DARPP-32 mRNA was different from that of its genome, indicating that the 2 mRNAs may be derived by alternate splicing of a single precursor mRNA.

The regional distribution of DARPP-32 mRNA in bovine CNS was examined by Northern blot hybridization with the antisense RNA (Fig. 7). DARPP-32 mRNA was highly concentrated in the caudate nucleus. This region in the bovine brain corresponds to the caudatoputamen in the rat brain, in which the rat DARPP-32 protein is highly enriched, as shown by in vitro back-phosphorylation (Walaas and Greengard, 1984), immunocytochemistry (Ouimet et al., 1984), and radioimmunoassay (Hemmings and Greengard, 1986). Similar results were obtained in the bovine brain by distribution analysis with immunoprecipitation, back-phosphorylation, and Western blot analysis (J.-A. Girault, personal communication). The caudate nucleus in the bovine brain and the caudatoputamen in the rat brain are known to receive a strong dopaminergic input, and both the cell bodies and dendrites of dopaminoceptive cells are present in these regions. The enrichment of DARPP-32 mRNA in this region correlates with the enrichment of the protein.

Distribution studies of DARPP-32 in the rat brain demonstrated that the substantia nigra is another region highly enriched in the protein (Hemmings and Greengard, 1986; Walaas and Greengard, 1984). It should be noted that only the axons and the nerve terminals of the dopaminoceptive cells are present in the substantia nigra. Northern blot hybridization analysis demonstrated that the level of DARPP-32 mRNA in the substantia nigra was low (3\%) compared with the caudate nucleus. These results indicate that the DARPP-32 gene is expressed in the caudate nucleus and that most of the DARPP- 32 mRNA is present in neuronal cell bodies. The physiological significance, if any, of the small amount of mRNA present in the substantia nigra is not clear at present. Cerebellum, hippocampus, and medulla white matter also contained low concentrations of DARPP-32 mRNA ( $<2 \%$ of that of caudate nucleus). Slightly higher concentrations (approximately $3 \%$ of that of caudate nucleus) were detected in cerebral cortex. The upper band $(1.8 \mathrm{~kb})$ was detected in all regions, while the lower band was not detectable in these regions, probably because of the low concentrations (Fig. 7, lanes 1, 2, 4-6). Although it is not yet clear whether the $1.65 \mathrm{~kb}$ band represents DARPP-32 mRNA or another cross-hybridizable mRNA species, the $1.8 \mathrm{~kb}$ band in these regions most likely represents DARPP-32 mRNA, since the cDNA clone pTKD7 encoding the DARPP-32 protein was derived from the 1771 nucleotide mRNA. Biochemical studies (Walaas and Greengard, 1984) and radioimmunoassays (Hemmings and Greengard, 1986) on the regional distribution of the protein indicate that many neurons contain low concentrations of DARPP-32. Walaas and Greengard (1984) showed that the lower brain stem, hypothalamus, and hippocampus of the rat do contain small amounts of the DARPP-32 protein. Immunocytochemical studies have also shown that the neurons in layers III and VI throughout most of the cerebral cortex, the Purkinje cells of the cerebellum, and certain glial cells are also weakly immunoreactive for the protein (Ouimet et al., 1984). In situ hybridization experiments using the antisense RNA probe derived from pTKD7G3 are in progress to determine the precise cellular localization of DARPP-32 mRNA in the mammalian brain.

In conclusion, we have isolated a cDNA clone that encodes a neuron-specific phosphoprotein, DARPP-32. We have found 2 species of mRNA for DARPP-32, which are probably derived from a single copy of the gene via alternative splicing. The mRNAs were found to be highly enriched in the caudate nucleus compared with other regions of the brain. Further study of this gene should provide a basis for a detailed investigation of the regulatory mechanisms of neuron-specific expression and developmental expression within the brain. Furthermore, the physiological role of DARPP-32 can now be investigated using an isolated gene-expression system.

\section{References}

Aviv, H., and P. Leder (1972) Purification of biologically active globin messenger RNA by chromatography on oligothymidylic acid-cellulose. Proc. Natl. Acad. Sci. USA 69: 1408-1412.

Birnboim, H. C., and J. Doly (1979) A rapid alkaline extraction procedure for screening recombinant plasmid DNA. Nucleic Acids Res. 7: 1513-1523.

Chirgwin, J. M., A. E. Przybyla, R. J. MacDonald, and W. J. Rutter (1979) Isolation of biologically active ribonucleic acid from sources enriched in ribonuclease. Biochemistry 18: 5294-5299.

Crick, F. H. C. (1966) The wobble hypothesis. J. Mol. Biol. 19: 548555.

Grantham, R., C. Gautier, M. Gouy, M. Jacobzone, and R. Mercier (1981) Codon catalog usage is a genome strategy modulated for gene expressivity. Nucleic Acids Res. 9: r43-r74.

Grunstein, M. M., and D. S. Hogness (1975) Colony hybridization: A method for the isolation of cloned DNAs that contain a specific gene. Proc. Natl. Acad. Sci. USA 72: 3961-3965.

Helfman, D. M., J. R. Feramisco, J. C. Fiddes, G. P. Thomas, and S. $\mathrm{H}$. Hughes (1983) Identification of clones that encode chicken tropomyosin by direct immunological screening of a cDNA expression library. Proc. Natl. Acad. Sci. USA 80: 31-35.

Hemmings, H. C., Jr., and P. Greengard (1986) DARPP-32, a dopamine- and adenosine $3^{\prime}: 5^{\prime}$-monophosphate-regulated phosphoprotein: Regional, tissue, and phylogenetic distribution. J. Neurosci. 6: $1469-1481$.

Hemmings, H. C., Jr., P. Greengard, H. Y. Lim Tung, and P. Cohen (1984a) DARPP-32, a dopamine-regulated neuronal phosphoprotein, is a potent inhibitor of protein-phosphatase-1. Nature 310:503505.

Hemmings, H. C., Jr., A. C. Nairn, D. W. Aswad, and P. Greengard (1984b) DARPP-32, a dopamine- and adenosine $3^{\prime}: 5^{\prime}$-monophosphate-regulated phosphoprotein enriched in dopamine-innervated brain regions. II. Purification and characterization of the phosphoprotein from bovine caudate nucleus. J. Neurosci. 4: 99-1 10.

Hemmings, H. C., Jr., A. C. Nairn, and P. Greengard (1984c) DARPP32 , a dopamine- and adenosine $3^{\prime}, 5^{\prime}$-monophosphate-regulated neuronal phosphoprotein. II. Comparison of the kinetics of phosphorylation of DARPP-32 and phosphatase inhibitor-1. J. Biol. Chem. 259: 14491-14497.

Hemmings, H. C., Jr., K. R. Williams, W. H. Konigsberg, and P. Greengard (1984d) DARPP-32, a dopamine- and adenosine $3^{\prime}: 5^{\prime}$-mono- 
phosphate-regulated neuronal phosphoprotein. I. Amino acid sequence around the phosphorylated threonine. J. Biol. Chem. 259: $14486-14490$.

Kozak, M. (1986) Point mutations define a sequence flanking the AUG initiator codon that modulates translation by eukaryotic ribosomes. Cell 44: 283-292.

Lagacè L., T. Chandra, S. L. C. Woo, and A. R. Means (1983) Identification of multiple species of calmodulin messenger RNA using a full length complementary DNA. J. Biol. Chem. 258: 1684-1688.

Maniatis, T., E. F. Fritsch, and J. Sambrook (1982) Molecular Cloning. A Laboratory Manual, Cold Spring Harbor Laboratory, Cold Spring Harbor, NY.

Melton, D. A., P. A. Krieg, M. R. Rebagliati, M. Maniatis, K. Zinn, and M. R. Green (1984) Efficient in vitro synthesis of biologically active RNA and RNA hybridization probes from plasmids containing a bacteriophage SP6 promoter. Nucleic Acids Res. 12: 7035-7056.

Messing, J. (1983) New M13 vectors for cloning. Methods Enzymol. 101: $20-78$.

Messing, J., R. Crea, and P. H. Seeburg (1981) A system for shotgun DNA sequencing. Nucleic Acids Res. 9: 309-321.

Nelson, F. K., S. M. Fredman, and G. P. Smith (1981) Filamentous phage DNA cloning vectors: A noninfective mutant with a nonpolar deletion in gene III. Virology 108: 338-350.

Okayama, H., and P. Berg (1982) High-efficiency cloning of full-length cDNA. Mol. Cell. Biol. 2: 161-170.

Ouimet, C. C., H. C. Hemmings, Jr., and P. Greengard (1984) DARPP32 , a dopamine- and adenosine $3^{\prime}, 5^{\prime}$-monophosphate-regulated phosphoprotein enriched in dopamine-innervated brain regions. III. Immunocytochemical localization. J. Neurosci. 4: 111-124.

Proudfoot, N. J., and G. G. Brownlee (1976) 3' non-coding region sequences in eukaryotic messenger RNA. Nature 263: 211-214.

Sanger, F., S. Nicklen, and A. R. Coulson (1977) DNA sequencing with chain-terminating inhibitors. Proc. Natl. Acad. Sci. USA 74: 5463-5467.
Setzer, D. R., M. McGrogan, J. H. Nunberg, and R. T. Schimke (1980) Size heterogeneity in the 3 ' end of dihydrofolate reductase messenger RNAs in mouse cells. Cell 22: 361-370.

Southern, E. (1975) Detection of specific sequences among DNA fragments separated by gel electrophoresis. J. Mol. Biol. 98: 503-517.

Thomas, P. S. (1980) Hybridization of denatured RNA and small DNA fragments transferred to nitrocellulose. Proc. Natl. Acad. Sci. USA 77: 5201-5205.

Vieira, J., and J. Messing (1982) The pUC plasmids, and M13mp7derived system for insertion mutagenesis and sequencing with synthetic universal primers. Gene 19: 259-268.

Walaas, S. I., and P. Greengard (1984) DARPP-32, a dopamine- and adenosine $3^{\prime}, 5^{\prime}$ monophosphate-regulated phosphoprotein enriched in dopamine-innervated brain regions. I. Regional and cellular distribution in rat brain. J. Neurosci. 4: 84-98.

Walaas, S. I., D. W. Aswad, and P. Greengard (1983) A dopamineand cyclic AMP-regulated phosphoprotein enriched in dopamine innervated brain regions. Nature 301: 69-71.

Williams, K. R., H. C. Hemmings, Jr., M. B. LoPresti, W. H. Konigsberg, and P. Greengard (1986) DARPP-32, a dopamine- and cyclic AMP-regulated neuronal phosphoprotein: Primary structure and homology with protein phosphatase inhibitor-1. J. Biol. Chem. 261: $1890-1903$.

Wood, W. B. (1966) Host specificity of DNA produced by Escherichia coli: Bacterial mutations affecting the restriction and modification of DNA. J. Mol. Biol. 16: 118-133.

Zelenka, P., and J. Piatigorsky (1974) Isolation and in vitro translation of d-crystallin mRNA from embryonic chick lens fibers. Proc. Natl. Acad. Sci. USA 71: 1896-1900.

Zinn, K., D. DiMaio, and T. Maniatis (1983) Identification of two distinct regulatory regions adjacent to human $\beta$-interferon gene. Cell 34: 865-879. 